\title{
Potency Of Oil Palm Empty Fruit Bunches (Opefb) In The Medical Field
}

\author{
Nur Hidayah ${ }^{1}$ \\ ${ }^{1}$ Sari Mulia School of Health Science \\ *nur_hidayah@stikessarimulia.ac.id
}

\begin{abstract}
Objective: The research aims at explaining the potency of oil palm empty fruit bunches (OPEFB) as a material in the medical field

Technology or method: This study used a method of literature review of some previous research on the utilization of oil palm empty fruit bunches. Furthermore, the results of previous studies were analyzed and compared to obtain the appropriate method for maximum cellulose isolation results.

Results: OPEFB still contains 44,4\% cellulose, 30,9\% hemicellulose and 14,2\% lignin. The content of cellulose is big enough to make OPEFB have the potential to be utilized as a product in the medical field. In the medical field, cellulose can be applied as a coating material on medicines, blood coagulants, facilitators in regeneration of injured cellular tissue, addictive to pharmaceutical products, supporting materials on immobilization of enzymes, artificial kidney membranes and tissue implantation materials.

Conclusion: Oil palm empty fruit bunches (OPEFB) has the potential to be utilized as a product in the medical field.
\end{abstract}

Keyword:, Cellulose, Medical field, Oil palm empty fruit bunches

\section{INTRODUCTION}

Oil palm empty fruit bunches are the largest solid waste generated from the palm oil processing industry. Based on the Ministry of Agriculture's report on 2014, every ton of fresh palm fruit processing will produce about $230 \mathrm{~kg}$ or $23 \%$ of empty bunches of palm oil bunches [1]. The waste look of palm oil empty bunches is a collection of thick brown fibers. This waste is the yield produced from the process of fresh palm fruit through the rotary drum thresher at the palm oil processing plant. OPEFB has an irregular shape.

OPEFB is distinguished by the maturity level of fresh fruit bunches (FFB) known as the fraction. The OPEFB faction consists of three types. First, the OPEFB with the fraction of the fruit is immature. This type of fraction looks intact and very dense, weighs less than $2 \mathrm{Kgs}$, the number of ripe fruit that has been released from bunches ranges up to $40 \%$, the stalk is difficult to decipher because it is still solid and spikelet, fruit and calyx are still firmly attached to the bunch. This fraction is called the Type I fraction. The type II fraction is OPEFB with the number of ripe fruits released from the bunches reaching $75 \%$. Mature fruit in this type has a characteristic intact and compact. Just like type I, spikelet, fruit and calyx still cling strongly to the bunches to make the bunches of fiber still difficult to decipher. As for the Type III fraction, $90 \%$ of the ripe fruit has been removed from the bunch due to the fragile and not solid bunches. In addition, the spikelet is not sticking strongly on the stalk so that fiber is easier to decipher. Visualization of the above three types can see below [2]. 


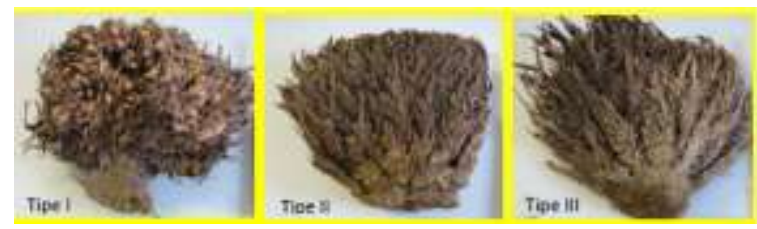

Figure 1. Types of OPEFB commonly encountered in Palm Oil Factory

Physically, empty palm oil bunches have a moisture content of about $60 \%$ and a maximum oil content of $2.5 \%$ and $23-35 \%$ fiber [2]. The average OPEFB weighs $3.5 \mathrm{Kg}$ with a thickness of $130 \mathrm{~mm}$ and the bunch length varies between $170-300 \mathrm{~mm}$ as well as a width of 250-350 $\mathrm{mm}$ [3]. OPEFB consists of spikelet content of $57,2 \%$, stalk (bunch basis) $21,2 \%$, calyx $9,1 \%$, thorn $5,1 \%$ and other components as much as 5\% [1]. The morphological data of oil palm empty bunches is given in Table 1.

Table 1. OPEFB Morphology [2]

\begin{tabular}{llll}
\hline No & Parametric & $\begin{array}{l}\text { OPEFB } \\
\text { section } \\
\text { base }\end{array}$ & $\begin{array}{l}\text { OPEFB } \\
\text { edge } \\
\text { section }\end{array}$ \\
\hline 1 & Fiber Length, mm & & \\
& - Minimum & 0.63 & 0.64 \\
& - Maximum & 1.81 & 1.27 \\
& - Avarage (L) & 1.20 & 0.76 \\
2 & Fiber Diametric (D), $\mu \mathrm{m}$ & 16.89 & 14.34 \\
3 & Lumen Diametric (D), $\mu \mathrm{m}$ & 8.04 & 6.99 \\
4 & Wall Thickness (w), $\mu \mathrm{m}$ & 3.49 & 3.68 \\
5 & Runkel Numbers (2w/l) & 0.87 & 1.05 \\
6 & Slender (L/D) & 79.95 & 53.0 \\
7 & Weakness (1/D) & 0.54 & 0.49 \\
8 & Fiber Content (\%) & 72.67 & 62.47 \\
9 & Fiber opening (\%) & 27.33 & 37.53 \\
10 & Bulk density kg/m ${ }^{3}$ & 177.98 & \\
\hline
\end{tabular}

In addition to containing the above components, the waste bunches of oil palm empty produced are known to still have a large enough cellulose content. Oil palm empty bunches contain $44.4 \%$ cellulose, $30.9 \%$ hemicellulose and $14.2 \%$ lignin. Cellulose is a major part of plant biomass especially. Cellulose becomes the builder or constituent of one-third to one-half of the entire plant tissue trunked. Cellulose is a natural polymer consisting of D-glucose anhydrous $\left(\mathrm{C}_{6} \mathrm{H}_{11} \mathrm{O}_{5}\right)$ binding to 1,4-b-Dglycosidic at position $\mathrm{C} 1$ and $\mathrm{C} 4$.

Table 2. Chemical Component of OPEFB [2]

\begin{tabular}{|c|c|c|c|}
\hline \multirow[b]{2}{*}{ No } & \multirow[b]{2}{*}{ Parameter } & \multicolumn{2}{|c|}{ Nilai $(\%)$} \\
\hline & & $\begin{array}{l}\text { Herawan dan } \\
\text { Rivani (2010) }\end{array}$ & $\begin{array}{l}\text { Erwinsyah } \\
\text { et al (2012) }\end{array}$ \\
\hline 1 & Extract & 7.78 & 5.22 \\
\hline 2 & Ash Content & 6.23 & 2.00 \\
\hline 3 & Cellulose & 37.50 & 41.09 \\
\hline 4 & Hemicellulose & 28.57 & - \\
\hline 5 & Holoselulosa & - & 69.33 \\
\hline 6 & Pentosan & 26.69 & 29.37 \\
\hline 7 & $\begin{array}{l}\text { Solubility in } 1 \% \\
\mathrm{NaOH}\end{array}$ & 29.96 & 24.69 \\
\hline
\end{tabular}

Cellulose is a polymer of $\beta$-glucose with $\beta-1-4$ bonds between glucose units. These compounds are commonly found in fibrous plants such as wood, cotton, hemp, palm and other plants. Based on its forming structure, cellulose has a large number of - $\mathrm{OH}$ groups to form hydrogen bonds with water so as to have the large solubility in water. However, cellulose is an insoluble compound in water and in other solvent compounds. This is due to chain stiffness and high inter-chain forces due to hydrogen bonds between adjacent hydroxyl groups. This condition makes cellulose has a high ability to form into crystals [4].

Components of cellulose, hemicellulose and lignin chemicals can be converted into higher-value products such as bioethanol [5,6,7,8], lactic acid [9], bio-composites [10], biopolimer / bioplastics [11], cellulose acetate [12], microbial cellulose $[13,14,15]$ and other products [1]. 
Cellulose fibers extracted from organic matter can be divided into two types namely, cellulose microfibrils and microcrystals of cellulose. Cellulosic microfibrils are cellulose fibers destroyed into sub-structural fibrils with microfibril lengths in micron scale and wide quantities ranging from 10 to hundreds of nanometers. Cellulosic microfibrils generally form a stable aqueous suspense. Cellulose fibers of this type are commonly used as thickeners, emulsifiers or additives in foods, mixtures of paints and coatings and additives to cosmetics and materials for health products [16]. Cellulose microcrystals are crystalline blocks adjacent to random amorphous blocks along cellulose fibers [17]. This type of cellulose usually has a diameter of $1-100 \mu \mathrm{m}$ with a crystalline percentage of $55 \%-85 \%$ [18]. Cellulose microcrystals have mechanical properties, viscosities and can form a layer of property so that these materials can potentially be utilized in the paper industry, cartons, cigarette filters, battery separators, and so forth [19,20,21].

In the last ten years, cellulose utilization research began to be developed in the world of health. Several studies both from within and outside have shown good results in the process of cellulose isolation and the utilization of cellulose as a material in the world of health. Cellulose particles can be used for fillers for polymer boosters, additives for biodegradable products, membrane boosters and others [22].

\section{METHOD AND PROCEDURE}

To get high cellulose content from empty bunches of oil palm, it is necessary to do some treatment. The process of cellulose isolation from basic biomass can be done in several ways ie physics, chemistry, heat and radioactive use. The comparison of the isolation methods is presented in Table 3.

Table 3. Method of cellulose isolation [23]

\begin{tabular}{|c|c|c|}
\hline No & Type of energy input & Mode of Action \\
\hline 1 & Chemical & $\begin{array}{l}\text { - Acid hydrolysis } \\
\text { - Enzymatic hydrolysis } \\
\text { - Alkaline degradation } \\
\text { - Oxidative degradation }\end{array}$ \\
\hline 2 & Mechanical & $\begin{array}{l}\text { - Dry milling } \\
\text { - Wet milling and } \\
\text { shearing } \\
\text { - Ultrasonic agitation }\end{array}$ \\
\hline 3 & Thermal & $\begin{array}{l}\text { - Thermal treatment at } \\
\text { different levels of } \\
\text { temperatures } \\
\text { various media }\end{array}$ \\
\hline 4 & Radioactive & $\begin{array}{l}\text { - Exposure to } \\
\text { UV/visible radiation } \\
\text { - Exposure to high } \\
\text { energy radiation }\end{array}$ \\
\hline
\end{tabular}

The process of cellulose isolation can use microorganisms such as Trichoderma resei, Trichoderma longbractium, Trichoderma harzianum, $T$. hamatum, $T$. koningii, T. pseudokongii, T. pilulifemm, T. aureoviride and Aspergillus terreus [24].

In general, cellulose extraction methods of empty palm oil bunches can be described in the following flow diagrams: 


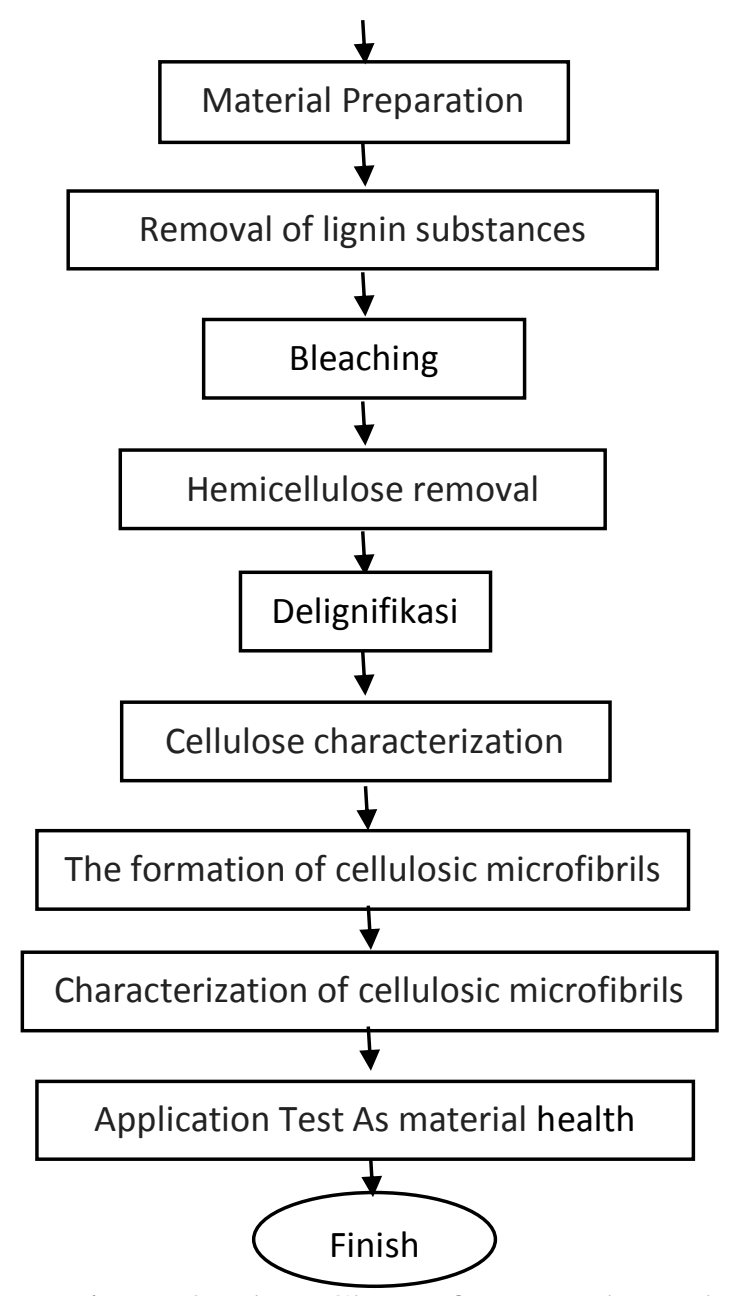

Figure 3. Flow Chart of Research Methods

The process of preparation of OPEFB material samples is generally done by washing, drying and cutting. The washing process aims to remove sap and dirt from OPEFB. The drying process can be done with the use of sunlight or use the oven. This phase aims to reduce the moisture content. While the cutting stage aims to facilitate the grinding process to obtain a more smooth fiber.

In the phase of removal of waxy substances is done by adding $\mathrm{KOH}$ solution as a solution for soaking the sample for 12 hours. Next bleaching process using hypochlorite for 5 hours. To return the $\mathrm{pH}$ of the sample under neutral conditions a sample washable with RO water after bleaching process. The next process is to remove the hemicellulose content by reacting the sample with $4 \mathrm{wt} \% \mathrm{NaOH}$ solution soaked in water bath at $60^{\circ} \mathrm{C}$ for 4 hours. The sample was then filtered using a vacuum pump and washed with distilled water. Reduced or loss of hemicellulose can result in a hole between fibrils so that the bonds between fibers decreases.

The delignification stage aims to reduce or eliminate the lignin layer in the sample. The delignification process can be divided into three types of treatment, namely mechanical pulping, chemical pulping and semi-chemical pulping. The mechanical pulping treatment is the simplest process among other delignification processes. This process only utilizes changes in mechanical properties so that the content of lignin substances is reduced only slightly. While in chemical pulping, lignin removal process is assisted by using chemicals at predetermined conditions (temperature, pressure, concentration and time have been determined first). At this stage, the sample is immersed using a chemical solution. There are two kinds of chemical pulping processes that are commonly used based on chemicals. First, the process of soda, where this process is included in alkaline processes such as $\mathrm{NaNO}_{2}$, $\mathrm{NaOH} \mathrm{Na}_{2} \mathrm{SO}_{3}$ and $\mathrm{NaOCl}$. The second process is the sulfate process with the solution used is usually acidic as $\mathrm{HNO}_{3}$.

The result of the next series of processes is a characterization of cellulose 
fibers using Fourier Transform Infrared (FTIR) spectroscopy method. This method is based on the difference in the absorption of infrared radiation by a material molecule. Based on these differences it can be seen functional groups contained in the sample. Spectrum FTIR was recorded with a $2 \mathrm{~cm}^{-1}$ spectrum separation at $20^{\circ} \mathrm{C}$ with $\mathrm{KBr}$ plate method. The next test is the Thermal Gravimetric Analysis (TGA) test. This test is based on measurements of a sample mass that is con fi native to a sensitive balance sheet (heat balance) when the sample temperature is raised in an air or in an inert atmosphere. The analysis is carried out at temperatures below $500^{\circ} \mathrm{C}$. High-Pressure Liquid Chromatography (HPLC) test aims to determine the effectiveness of hemicellulose removal. This test is an analysis for sugar monosaccharides based on retention time. Other tests carried out to determine the molecular group and the degree of crystallinity in the fiber sample was by using X-ray Diffraction (XRD) test [21, 25]

Successfully characterized cellulose fibers are further isolated to form cellulose microfibrils. One type of cellulosic microfibrils is in the form of nanofiber. Nanofiber cellulose can be formed by shrinking the size of cellulose using a grinder such as waring blender. The grinding time can last for $4-10$ minutes. The sample is then dispersed into aquadest and stirred to form a suspension. To form a suspense that has a high viscosity then the suspense is formed then passed into the ultrafine grinder. High viscosity suspensions are then synthesized using ultrasonic homogenizers to produce cellulosic nanofiber. To know the characteristics and morphology of nanofiber produced, was used scanning electron microscopy (SEM) test. Meanwhile, to determine the water absorption and strength of pull then also need to do mechanical testing on cellulose [25].

The formation becomes microcrystalline and cellulosic nanocrystals are performed by hydrolysis using acid solutions such as $\mathrm{HCl}, \mathrm{H}_{2} \mathrm{SO}_{4}$ and other types of acid solutions. The hydrolysis sample is subsequently cooled and washed with an alkaline solution and soaked with aquadest. The samples of soak and aquadest are added in a certain amount of time to form tension. The subsequent suspension is centrifuged to neutralize the $\mathrm{pH}$ and separate the cellulosic microcrystalline formed from the filtrate. The microstructure of the crystals is then chewed and dried to allow the water content to be removed. To characterize microcrystalline cellulose form SEM testing. This test aims to determine the resulting microcrystalline [25].

\section{RESULT AND DISCUSSION}

Several studies successfully isolate the cellulose from OPEFB with the results of the rate of cellulose $69,55 \%$, lignin and hemicellulose $17,76 \% 5,82 \%$. The level of section $58,1 \%$ of cellulose. This degree of magnitude claimed that cellulose is generated 
has the power harness is good enough. For micro characterization of nanofiber morphology of cellulose produced measuring $30 \mathrm{~nm}$. These results obtained by a testing method based on SEM. Nanofiber generated then happens formed into hydrogel for mediation is used as a cover to medium wounds.

The use of acidic compounds on cellulose isolation process shows a more optimal result compared to using alkaline compounds as substances of the reactant.
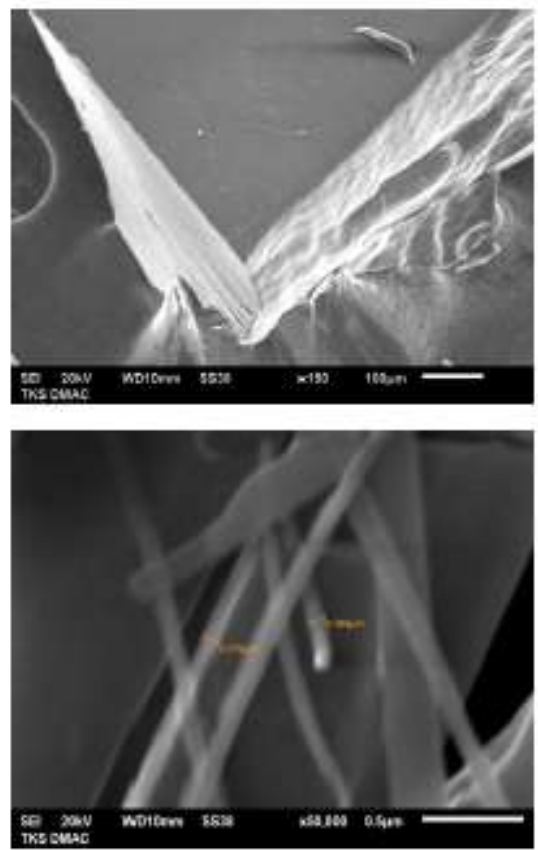

Figure 4. SEM Result of Cellulose Microcrystals [25]

Figure 4 (at the top) shows SEM results with 150x magnification. From the top of the picture there is a set of agglomerated crystals. In the image below with 5000x magnification showing a single crystal with density between 79 - $84 \mathrm{~nm}$.

\section{CONCLUSION}

Research on the utilization of cellulose from empty palm oil bunches has the potential to be developed in the world of health in Indonesia. Given the abundance of biomass contents generated from agriculture, plantation and industry, especially upstream and downstream industries of oil palm. In addition to solving the waste problem generated from the palm oil industry, this research is expected to also be able to overcome the problem of Indonesia's health depends on the import of health materials from outsiders. But this research has to go through several stages. The first stage can be started from the determination of the best isolation method to obtain high cellulose content from empty palm oil bunches. Further research is focused on finding the right parameters and methods for the utilization of cellulose as a material for the health world can be done optimally

\section{REFERENCE}

[1] Herawan, T., Rivani, M. Pemanfaatan Limbah Padat Kelapa Sawit untuk Produksi Green Product. Prosiding Pertemuan Teknis Kelapa Sawit 2013. JCC Jakarta 7-9 Mei 2013. ISBN 978602-7539-16-7, pp. 181-190. 2013.

[2] Erwinsyah, Afriani Atika dan Kardiansyah Teddy. Potensi dan Peluang Tandan Kosong Sawit Sebagai Bahan Baku Pulp dan Kertas: Studi Kasus di Indonesia. Jurnal Selulosa Vol. 5 No. 2: pp. 79-88. 2015.

[3] Chang, S.H. An Overview of Empty Fruit Bunch From Oil Palm as Feedstock for Bio-oil Production, Biomass \& Bioenergy, 1-8. 2014.

[4] Cowd, M.A, Kimia Polimer, Bandung: Penerbit ITB. 1991. 
[5] Schell, D. J., Riley, C. J., Dowe N., Farmer J., Ibsen K., N Ruth, M. F., Toon, S.T., Lumpkin, R.E. A Bioethanol Process Development Unit: Initial Operating experiences and Results with A Corn Fiber Feedstock. Biosource Technology, 91, pp. 179-188. 2004.

[6] Kim, T. H., Taylor, F., Hicks, K. B. Bioethanol Production From Barley Hull Using SSA (Soakingin Aquaeos Ammonia) Pretreatment. Bioresource Technology, 99, pp. 5694-5702. 2008.

[7] Binod, P., Sindhu, R., Singhania, R.R., Vikram, S., Devi, L., Nagalaksmi, S., Kurien, N., Sukumaran, R. K., Pandey, A. Bioethanol Production From Rice Straw: An Overview, Bioresource Technology, 101, pp.4767-4774. 2010.

[8] Piarpuzan, D., J., A, Quintero, C.A. Cardano. Empty Fruit Bunches From Oil Palm as a Potential Raw Material For Fuel Ethanol Production. Biomass and Bioenergy 35: pp. 1130-1137. 2011.

[9] Venkatesh, K.V. Simultaneous Saccharification and Fermentation of Cellulose to Lactic Acid, Bioresource Technology, 61, pp. 91-98. 1997.

[10] Abe K, Iwamoto S, Yano H. Obtaining cellulose nanofibers with a uniform width of $15 \mathrm{~nm}$ from wood. J Biomacromolecus 8: pp. 3276-3278. 2007.

[11] Liew, T.K., King, L. S., Haur, C.J. dan Yu, L.C. Overview of Poly Lactica Acid Production with Oil Palm Biomass as Potential Feedstock. International Journal of Engineering and Applied Sciences. Vol. 5, no. 4, pp.1-10. 2014.

[12] Shaikh, H.M., Pandare, K.V., Nair, G., Varma, A.J. Utilization of Sugarcane Bagasse Cellulose For Producing Cellulose Acetate: Novel Use of Residual Hemicullose as Plasticizer. Carbohydrate Polymers 76, pp. 23-29. 2009.

[13] Bhattacharya, D., Germinario, L.T., Winter, W.T. Isolation, Preparation and Characterization of Cellulose Microfibers Obtained From Bagasse, Carbohydrate Polymers, 73, pp. 371-377. 2008.

[14] El-Sakhawy, M., Hassan, M.L. Physical and Mechanical Properties of Microcrystalline Cellulose Prepared From Agricultural Residues,
Carbohydrate Polymers, 67, pp.1-10. 2007.

[15] Hafiz M., Eichhorn S.J., Hasan A and Jawaid M, Isolation and Characterization of Microcrystal line Cellulose From Oil Palm Biomass Residue, Universiti Teknologi Malaysia, Johar. 2013.

[16] Harahap, Mahyuni, Thamrin and Saharman Gea, Pembuatan Selulosa Asetat dari $\alpha$ Selulosa yang Diisolasi dari Tandan Kosong Kelapa Sawit, Jurnal FMIPA USU. 2012.

[17] Caviello T, Matricardi P, Marienecci C, Alhaiue F. Polysaccharide hydrogel for modified release formulation. $J$ Controlled Release 119: pp. 5-24. 2007.

[18] Qianxiang, Y Y, Lee, Par O, Petterson and Robert W. Heterogenous Aspect of Acid Hydrolysis of $\alpha$-Cellulose. Auburn: University Auburn. 2003.

[19] Caviello T, Matricardi P, Marienecci C, Alhaiue F. Polysaccharide hydrogel for modified release formulation. $\mathbf{J}$ Controlled release 119: pp. 5-24. 2007.

[20] Fahma F, Iwamoto S, Hori N, Iwata T, Takemura A. Isolation, preparation, and characterization of nanofibers from oil palm empty-fruit-bunch (OPEFB). J Cellulose 17: pp. 977-985. 2010.

[21] Andri Nosya Muhammad, Pembuatan Mikrokristal Selulosa Dari Tandan Kosong Kelapa Sawit, Tugas Akhir Mahasiswa Universitas Lampung. 2016.

[22] Leolovich, M, Optimal Conditions for Isolations of Nanocrystalline Cellulose Particles. Nanoscience and Nanotechnology. 2(2), pp. 9-13. 2012.

[23] Satriawan, N. E and Meidi Ferdian. Elektrospinning Nanoselulosa Sebagai Material Benang Operasi dan SIstem Penghantar Obat. Jurnal Nanomaterial dan Ilmu Bahan Medis. 2015.

[24] Surya Rudy Sitorus. Pretreatment dan Hidrolisis Tandan Kosong Kelapa Sawit (OPEFB) dengan Metode Steaming dan Enzimatik. Skripsi Departemen Teknik Kimia Fakultas Teknik Universitas Indonesia. Depok. 2011.

[25] Ayu Faiza Lestari. Pembuatan Hidrogel Nanofiber Selulosa dari Tandan Kosong Kelapa Sawit (OPEFB). Tugas Akhir 
Mahasiswa Institut Pertanian Bogor. 2016. 